\title{
Hysterectomy: retrospective analysis of 476 cases
}

\section{Parul Bhugra*}

Department of Obstetrics and Gynecology, Pt. B. D. Sharma PGIMS, Rohtak, Haryana, India

Received: 03 February 2020

Revised: 22 February 2020

Accepted: 29 February 2020

\section{*Correspondence:}

Dr. Parul Bhugra,

E-mail: parul01kalra@gmail.com

Copyright: () the author(s), publisher and licensee Medip Academy. This is an open-access article distributed under the terms of the Creative Commons Attribution Non-Commercial License, which permits unrestricted non-commercial use, distribution, and reproduction in any medium, provided the original work is properly cited.

\section{ABSTRACT}

Background: Diseases of the female genital tract are commonly encountered in clinical practice. Hysterectomy is the definite treatment for many of the pelvic pathologies. The present study is aimed at analysis of age and types of hysterectomy and evaluation of histopathological reports of the hysterectomy specimens.

Methods: A total of 476 consecutive hysterectomy were studied over a period of two years from January 2016 to December 2017.

Results: The peak age group of hysterectomy was 41-50 years with $221(46.43 \%)$ cases. The commonest type of hysterectomy was abdominal. The most common endometrial pathology was atrophic endometrium, seen in 131 $(27.52 \%)$ cases. In myometrium, the most common pathology was leiomyoma in $179(37.61 \%)$ cases. Among cervical lesions, chronic cervicitis was the most common finding, seen in $274(57.56 \%)$ cases.

Conclusions: The experience with various types of hysterectomies at our institution has been reviewed. A wide spectrum of lesions were observed when histopathology reports of the hysterectomy specimens were analysed.

Keywords: Abdominal hysterectomy, Cervix, Endometrium, Hysterectomy, Laparoscopic hysterectomy, Myometrium, Vaginal hysterectomy

\section{INTRODUCTION}

Hysterectomy is the second most commonly performed major surgical procedure in females worldwide next to caesarean section. ${ }^{1}$ It is a successful operation in terms of symptoms relief and patient satisfaction, and provides definite cure to many diseases involving the uterus like utero-vaginal prolapse, leiomyoma and adenomyosis. The hysterectomy can be performed via an abdominal or vaginal approach, or with laparoscopic assistance. Currently there is upward trend for vaginal and laparoscopic hysterectomy. ${ }^{2}$

A wide range of lesions were encountered when hysterectomy specimens were subjected to histopathological examination. The aim of the present study was to analyse age distribution, types of hysterectomy and histopathological reports of the hysterectomy specimens.

\section{METHODS}

The present study was carried out in the department of obstetrics and gynecology, Pt. B. D. Sharma PGIMS, Rohtak, Haryana. The study comprised of 476 consecutive hysterectomy procedures carried out over a period of 2 years from January 2016 to December 2017.

The study included hysterectomies for uterine and cervical indications. All the women who had hysterectomy for obstetric, ovarian and tubal conditions were excluded from the study. The available records of the patients were reviewed. Age, type of hysterectomy and final histopathological reports were analyzed. 


\section{Statistical analysis}

Statistical analysis was carried out by using SPSS v. 20.0. Descriptive statistics such as mean, number, percentage were observed.

\section{RESULTS}

A total of 476 hysterectomy procedures were studied retrospectively. The age ranged from 23 to 85 years. The mean age was 48.23 years. The most common age group which underwent hysterectomy was $41-50$ years with 221 $(46.43 \%)$ cases followed by $94(19.75 \%)$ cases in 51-60 years age group. The commonest type of hysterectomy was abdominal with $242(50.84 \%)$ cases followed by vaginal hysterectomy in $216(45.38 \%)$ cases.

Table 1: Age wise distribution of hysterectomy cases.

\begin{tabular}{|lll|}
\hline Age & No. of cases & Percentage \\
\hline $11-20$ & 0 & $0.00 \%$ \\
\hline $21-30$ & 23 & $4.83 \%$ \\
\hline $31-40$ & 89 & $18.70 \%$ \\
\hline $41-50$ & 221 & $46.43 \%$ \\
\hline $51-60$ & 94 & $19.75 \%$ \\
\hline $61-70$ & 45 & $9.45 \%$ \\
\hline$\geq 71$ & 4 & $0.84 \%$ \\
\hline Total & 476 & \\
\hline
\end{tabular}

Table 2: Distribution according to type of hysterectomy.

\begin{tabular}{|lll|}
\hline Type of hysterectomy & No. of cases & Percentage \\
\hline Abdominal & & \\
\hline $\begin{array}{l}\text { Total abdominal } \\
\text { hysterectomy (TAH) }\end{array}$ & 221 & $46.43 \%$ \\
\hline Wertheim's hysterectomy & 14 & $2.94 \%$ \\
\hline Extended hysterectomy & 7 & $1.47 \%$ \\
\hline Total & 242 & $50.84 \%$ \\
\hline $\begin{array}{l}\text { Vaginal hysterectomy } \\
\text { (VH) }\end{array}$ & 216 & $45.38 \%$ \\
\hline Laparoscope assisted & & \\
\hline $\begin{array}{l}\text { Total laparoscopic } \\
\text { hysterectomy (TLH) }\end{array}$ & 10 & $2.10 \%$ \\
\hline $\begin{array}{l}\text { Laparoscopically assisted } \\
\text { vaginal hysterectomy } \\
\text { (LAVH) }\end{array}$ & 8 & $1.68 \%$ \\
\hline Total & 18 & $3.78 \%$ \\
\hline
\end{tabular}

Among endometrial lesions, atrophic endometrium was the most common pathology seen in 131 (27.52\%) cases. Other endometrial pathologies observed were nonatypical hyperplasia, endometrial polyp, endometritis, adenocarcinoma and squamous cell carcinoma of the cervix extending into the endometrium. Leiomyoma was the most common myometrial pathology with 179 $(37.61 \%)$ cases followed by adenomyosis in $41(8.61 \%)$ cases. Other myometrial pathologies were leiomyoma associated with adenomyosis, adenocarcinoma of the endometrium invading into the myometrium and myometritis. Among cervical lesions, chronic cervicitis was the most common pathology seen in 274 (57.56\%) cases, followed by squamous cell carcinoma, endometrial carcinoma invading into the cervix, dysplasia and leiomyoma. The results of the study are summarised in Tables 1-5.

\section{Table 3: Histopathological lesions of endometrium.}

\begin{tabular}{|lll|}
\hline Endometrial lesions & No. of cases & Percentage \\
\hline Unremarkable & 322 & $67.65 \%$ \\
\hline Endometrial atrophy & 131 & $27.52 \%$ \\
\hline Non-atypical hyperplasia & 4 & $0.84 \%$ \\
\hline Polyp & 4 & $0.84 \%$ \\
\hline Endometritis & 2 & $0.42 \%$ \\
\hline Adenocarcinoma & 11 & $2.31 \%$ \\
\hline $\begin{array}{l}\text { Squamous cell carcinoma } \\
\text { of the cervix extending } \\
\text { into the endometrium }\end{array}$ & 2 & $0.42 \%$ \\
\hline
\end{tabular}

Table 4: Histopathological lesions of myometrium.

\begin{tabular}{|lll|}
\hline Myometrial lesions & No. of cases & Percentage \\
\hline Unremarkable & 210 & $44.12 \%$ \\
\hline Leiomyoma & 179 & $37.61 \%$ \\
\hline Adenomyosis & 41 & $8.61 \%$ \\
\hline $\begin{array}{l}\text { Leiomyoma with } \\
\text { adenomyosis }\end{array}$ & 33 & $6.93 \%$ \\
\hline $\begin{array}{l}\text { Endometrial } \\
\text { adenocarcinoma invading } \\
\text { into myometrium }\end{array}$ & 11 & $2.31 \%$ \\
\hline Myometritis & 2 & $0.42 \%$ \\
\hline
\end{tabular}

Table 5: Histopathological lesions of cervix.

\begin{tabular}{|lll|}
\hline Cervical lesions & No. of cases & Percentage \\
\hline Unremarkable & 189 & 39.71 \\
\hline Chronic cervicitis & 274 & 57.56 \\
\hline Dysplasia & 1 & 0.21 \\
\hline Squamous cell carcinoma & 10 & 2.10 \\
\hline $\begin{array}{l}\text { Endometrial carcinoma } \\
\text { involving cervix }\end{array}$ & 1 & 0.21 \\
\hline Leiomyoma & 1 & 0.21 \\
\hline
\end{tabular}

\section{DISCUSSION}

Uterus, a vital reproductive organ is subjected to variety of benign and malignant diseases. There has been a considerable improvement in the medical and conservative surgical procedures for uterine lesions but still hysterectomy may be required. The Indian incidence of hysterectomy is 6-8\% and rising. ${ }^{3}$ The increase in hysterectomies may be due to prophylaxis against uterine malignancy, in cases of mild genital prolapse and premenopausal menorrhagia. ${ }^{4}$ According to Dicker, hysterectomy is indicated when the risk of preserving the 
uterus is greater than the risk of its removal or when medical treatment is not successful in relieving the disabling symptoms. ${ }^{5}$

In this study out of 476 hysterectomies, abdominal route was used in $242(50.84 \%)$ cases, vaginal route in 216 $(45.38 \%)$ while laparoscopic assistance was used in 18 $(3.78 \%)$ cases. The ratio of abdominal to vaginal hysterectomy in the present study was 1.12:1. Studies reported by Ajmera et al and Kovac SR showed the ratio as $1.4: 1$ and $3: 1$ abdominal to vaginal hysterectomy respectively. ${ }^{6,7}$ The use of abdominal route though the highest is on the decline, reasons for increasing use of vaginal and laparoscopic hysterectomies include avoidance of large wounds on the abdominal wall, shorter period of hospitalization and lesser complications. ${ }^{8}$

In the present study, maximum number of patients i.e. $221(46.43 \%)$ were seen in the age group of $41-50$ years. In an analysis of 1000 consecutive operations by Watt et al9, maximum percentage of cases i.e. $45.2 \%$ were also distributed in the age group of 41-50 years. Other studies done by Rather et al, Ramchandran et al, and Dhulia et al, had similar findings. ${ }^{10-12}$

In this study, endometrium was unremarkable in 322 $(67.65 \%)$ cases. Studies done by Vani et al and Rather et al had distribution of unremarkable endometrium being $58.6 \%$ and $83 \%$ respectively. ${ }^{10,13}$ Atrophic endometrium was the most common endometrial pathology in the present study, noted in $131(27.52 \%)$ cases. This finding was comparable with the study done by Patel et al, which showed $29 \%$ cases of atrophic endometrium. ${ }^{14}$ Eleven $(2.31 \%)$ cases of endometrial carcinoma were encountered in the present study. This finding is close to that reported by Ankur et al. ${ }^{15}$

In the present study, myometrium was histologically normal in $210(44.12 \%)$ cases and leiomyoma was the most common myometrial pathology, detected in 179 $(37.61 \%)$ cases. These findings were comparable to that reported by Vani et al, they reported histologically normal myometrium in $44.28 \%$ and leiomyoma in $41.08 \%$ cases. $^{13}$ Adenomyosis was the second most common myometrial pathology in the present study, observed in $41(8.61 \%)$ cases. Adenomyosis is rarely diagnosed preoperatively and is usually diagnosed after hysterectomy by histopathological examination. ${ }^{16}$ Thirtythree $(6.93 \%)$ cases in this study revealed the presence of both leiomyoma and adenomyosis.

Chronic cervicitis is an extremely common condition in adult females, at least at the microscopic level. It was the commonest cervical pathology in this study, detected in $274(57.56 \%)$ cases. Patel et al and Rather et al reported chronic cervicitis in $28.1 \%$ and $89.3 \%$ cases respectively. ${ }^{10,14}$ Ten $(2.10 \%)$ cases of squamous cell carcinoma of the cervix were detected in this study. This finding is comparable to that reported by Patel et al. ${ }^{14}$

\section{CONCLUSION}

Conservative treatment of uterine lesions has been improved remarkably; still hysterectomy may be required. The choice of a particular type of hysterectomy depends on preoperative findings, the technical possibility of the setting, and the experience of the surgeon. The ultimate goal should be to choose the safest but at the same time least invasive surgical procedure. Histopathological examination of the hysterectomy specimens shows a wide range of lesions. The present study provides a fair insight into the spectrum of histopathological findings in hysterectomy specimens. Atrophic endometrium, leiomyoma and chronic cervicitis were the commonest pathologies of endometrium, myometrium and cervix respectively with a variety of other lesions. Histopathology not only confirms preoperative diagnosis but may also show pure incidental finding. Thus, it is mandatory to do a detailed histopathological examination of every hysterectomy specimen so as to ensure a better postoperative management.

\section{Funding: No funding sources}

Conflict of interest: None declared

Ethical approval: The study was approved by the Institutional Ethics Committee

\section{REFERENCES}

1. Wu JM, Wechter ME, Geller EJ, Nguyen TV, Visco AG. Hysterectomy rates in the United States, 2003. Obstet Gynecol. 2007;110:1091-5.

2. Fylstra DL, Carter JF. Laparoscopically assisted vaginal hysterectomy in a university hospital. Decreasing the need for abdominal hysterectomy and increasing resident experience in vaginal surgery. $\mathrm{J}$ Reprod Med. 1996;41:493-503.

3. Singh A, Arora AK. Why hysterectomy rate are lower in India. Indian J Commun Med. 2008;33:1967.

4. Olsson JH, Ellstrom M, Hahlin M. A randomised prospective trial comparing laparoscopic and abdominal hysterectomy. $\mathrm{Br} \mathrm{J}$ Obstet Gynaecol. 1996;103:345-50.

5. Dicker RC, Seally MJ, Greenspan JR, Layde PM, Ory HW, Maze JM, et al. Hysterectomy among women of reproductive age trends in United States. JAMA. 1990;248:328-35.

6. Ajmera SK, Mettler L, Jonat W. Operative spectrum of hysterectomy in a German university hospital. J Obstet Gynecol India. 2006;56:59-63.

7. Kovac SR. Transvaginal hysterectomy: rationale and surgical approach. Obstet Gynecol. 2004;103:13215 .

8. Garry R, Fountain J, Mason S, Hawe J, Napp V, Abbott $\mathrm{J}$, et al. The evaluate study: two parallel randomised trials, one comparing laparoscopic with abdominal hysterectomy, the other comparing 
laparoscopic with vaginal hysterectomy. $\mathrm{Br}$ Med J. 2004;328:129.

9. Watts WF, Kimbrough RA. Hysterectomy analysis of 1000 consecutive operations. Obstet Gynecol. 1956;7:483-93.

10. Rather GR, Gupta Y, Bardhwaj S. Patterns of lesions in hysterectomy specimens: a prospective study. JK Sci J Med Edu Res. 2013;15:63-8.

11. Ramachandran $T$, Sinha P, Subramanium. Correlation between clinicopathological and ultrasonographical findings in hysterectomy. J Clin Diag Res. 2011;5:737-40.

12. Dhuliya V, Gosai D, Jain H, Goswami H. Histopathological study of uterine and cervical lesion in hysterectomy specimen. BJkines - NJBAS. 2016;8:23-6.

13. Vani D, Pushpa HR, Srijana Rao SP, Bharathi M. Spectrum of histopathological findings in hysterectomy specimens - a retrospective - 5-year study. J Med Sci Clin Res. 2018;6:902-6.
14. Patel AS, Shah KJ. Histopathological analysis of hysterectomy specimens in tertiary care center: twoyear study. Trop J Pathol Microbiol. 2018;4:34-9.

15. Gupta A, Sehgal S, Yadav A, Kumar V. Histopathological spectrum of uterus and cervix in hysterectomy specimens. Int $\mathbf{J}$ Med Res Prof. 2016;2:136-9.

16. Shrestha A, Shrestha R, Sedhai LB, Pandit U. Adenomyosis at hysterectomy: prevalence, patient characteristics, clinical profile and histopathological findings. Kathmandu Univ Med J. 2012;37:53-6.

Cite this article as: Bhugra P. Hysterectomy: retrospective analysis of 476 cases. Int J Reprod Contracept Obstet Gynecol 2020;9:1930-3. 